\title{
JALUR EVAKUASI BENCANA DI KAWASAN PERKOTAAN (Study Kasus : Gunung Sahari Jakarta Pusat)
}

\author{
Abdurrahman ibnu auf ${ }^{1}$, Titin Woro Murtini ${ }^{2}$, Siti Rukayah ${ }^{3}$ \\ 1,2,3 Jurusan Arsitektur Fakultas Teknik, Universitas Diponegoro Semarang \\ Jl. Prof Sudarto SH Tembalang Semarang 50131
}

\begin{abstract}
ABSTRAK
Jalur pedestrian adalah jalur untuk pejalan kaki yang menghubungkan satu tempt ke tempat lainnya. Jalur pedestrian sangat dibutuhkan dalam sebuah kawasan kota. Jalur pedestrian dapat dikatakan juga sebagai ruang terbuka publik, karena pada jalur pedestrian ini dapat digunakan juga sebagai fasilitas untuk bersosialisasi antar individu. Selain itu juga pada jalur pedestrian yang aman dan nyaman bagi penggunanya, elemen-elemen pendukung juga harus disediakan. Berbagai fasilitas yang ada di jalur pedestrian dapat melengkapi fungsi jalur pedestrian sebagai ruang publik (maulani,dkk, 2013). Kawasan Gunung sahari jakarta pusat merupakan jalan utama dikota Jakarta yang memiliki jalur pedestrian, Jalur pedestrian pada Koridor Gunung Sahari mengalami peningkatan kegiatan yang cukup pesat menyusul meningkatnya perkembangan aktivitas dikoridor jalan tersebut (Rohman, 2015). Namun, peningkatan hanya disalah satu sisi saja, beberapa faktor menjadi penyebabnya. Melihat fenomena tersebut muncul pertanyaan mengapa tidak difungsikan kembali jalur tersebut?. Bencana merupakan salah satu hal yang dapat terjadi dimana, kapan, dan kepada siapa saja. Bencana dapat berupa bencana alam dan human eror. Penanggulangan bencana belum terlalu diperhatikan oleh masyarakat. Salah satunya jalur evakuasi bencana di kawasan kota. Tidak berfungsinya pedestrian di koridor gunung sahari layak untuk diteliti dan ditinjau apakah layak untuk difungsikan sebagai jalur evakuasi?
\end{abstract}

Keyword : Jalur pedestrian, Bencana, Jalur evakuasi kawasan kota

\section{PENDAHULUAN}

Koridor Jalan Gunung Sahari merupakan pusat pertumbuhan kota. Hal ini dikarenakan banyaknya aktivitas yang terjadi pada kawasan tersebut.Jalan Gunung Sahari sebagai salah satu jalan utama penghubung antara kawasan Pasar Senen menuju kawasan Mangga Dua, dan juga sebagai jalan alternatif menuju Kawasan Pantai Ancol. Dikoridor jalan ini terdapatmall Plaza Golden Trully, Halte Pemberhentian Trans Jakarta, dan keberadaan PKL di saat jam tertentu. Sehingga Jalan Gunung Sahari menjadi pilihan para karyawan/pegawai sebagai jalan utama menuju titik $A$ ke titik $B$, parkir kendaraan bermotor, bajai/ojek dan selain itu sebagai tempat menunggu kendaraan umum maupun pribadi untuk melanjutkan perjalanan yang diinginkan. Jalur pedestrian pada Koridor Gunung Sahari mengalami ketimpangan fungsi jalur pedestrian, salah satu sisi terlihat berfungsi dengan baik karena berdekatan dengan bangunan-bangunan besar. Namun disisi sebaliknya sepi pengguna jalur pedestrian.

Jalur pengguna pedestrian diharapkan dapat menyatu dengan lingkungannya dengan pola dan kondisinya yang sesuai dengan lingkungan sekitarnya. Dalam hal ini Shirvani (1985) mengatakan bahwa jalur pengguna pedestrian harus dipertimbangkan sebagai salah satu elemen perencanaan kota. Menurut Rubenstein (1992) tujuan dari pedestrian adalah untuk kesejahteraan, keamanan, kemudahan, kenyamanan dan keindahan. Ketika kriteria tersebut tidak terpenuhi maka jalur pedestrian harus dipertanyakan, apakah terdapat kegagalan desain atau memang lingkungan yang tidak mendukungnya. Pedestrian didalamnya, jalur evakuasi bencana juga merupakan faktor yang harus direncanakan pula.

Melihat kondisi lapangan diatas, maka penulis mencoba untuk meneliti koridor gunung sahari jakarta pusat, jalur evakuasi dan 
jalur pedestrian menjadi faktor utama yang akan dilihat.

\section{METODE}

Metode penelitian yang digunakan adalah kualitatif, dengan menjabarkan temuan yang ada dilapangan. Beberapa faktor dijadikan tolak ukur dalam penelitian ini, yaitu jalur pedestrian dan jalur evakuasi kota. Teori dijadikan sebagai background teori pembahasan penelitian.

\section{Teknik Pengumpulan Data}

Data (tunggal $=$ datum) adalah bahan keterangan tentang sesuatu obyek penelitian yang diperoleh di lokasi penelitian (Bungin, 2005). Definisi data sebenarnya mirip dengan definisi informasi, hanya saja informasi lebih menonjolkan segi pelayanan, sedangkan data lebih menonjolkan aspek materi. Selain data, ada juga pemahaman lain yang mirip dengan data yaitu fakta. Biasanya orang sering menggunakan dua istilah ini dalam satu penjelasan yang sama, padahal masing masing punya konsep yang berbeda. Metode pengumpulan data adalah bagian instrumen pengumpulan data yang menentukan berhasil atau tidaknya suatu penelitian (Bungin, 2005). Kesalahan menggunakan metode pengumpulan data atau metode pengumpulan data yang tidak digunakan semestinya, berakibat fatal terhadap hasil - hasil penelitian yang dilakukan.

Beberapa proses pendataan dilakukan, mulai dari oservasi awal, pengumpulan data lapangan, pengumpulan data pustaka, menyusun pustaka sebagai pedoman membuat kuesioner, hingga menyebaran kuesioner dilengkapi wawancara dan pemetaan lokasi penelitian.

\section{PENGERTIAN BENCANA PERKOTAAN}

Definisi bencana menurut Carter (1991) adalah suatu kejadian, alam atau buatan manusia, tiba-tiba atau progesive, yang menimbulkan dampak yang dahsyat (hebat) sehingga komunitas (masyarakat) yang terkena atau terpengaruh harus merespon dengan tindakan-tindakan luar biasa.Sedangkan Dalam UU No 24 tahun 2007 tentang penanggulangan bencana, bencana didefinisikan sebagai peristiwa atau rangkaian peristiwa yang mengancam dan mengganggu kehidupan dan penghidupan masyarakat yang disebabkan, baik oleh faktor alam dan/atau faktor nonalam maupun faktor manusia sehingga mengakibatkan timbulnya korban jiwa manusia, kerusakan lingkungan, kerugian harta benda, dan dampak psikologis. Sehingga dibutuhkan tindakan-tindakan penanggulangan bencana, tindakan ketika ada bencana dan setelah terjadi bencana. Dalam bahasan ini akan membahas mengenai tindakan menanggulangan bencana di perkotaan dan jalur evakuasi bencana.

Perkotaan tidak bisa lepas dari adanya bencana. Bencana yang dapat terjadi yaitu bencana yang terjadi secara alam dan bencana karena human eror. Bencana tersebut menjadi salah satu permasalahan kota juga.

\section{JALUR EVAKUASI PERKOTAAN}

Sejarah bencana yang pernah terjadi di Propinsi DKI Jakarta merupakan bencana alam dan non-alam serta bencana sosial akibat ulah manusia. Terdapat 9 potensi bencana yang teridentifikasi berdasarkan sejarah kejadiannya. Kelompok potensi bencana tersebut dapat dilihat pada Tabel.

Tabel 1. Sejarah bencana di DKI Jakarta

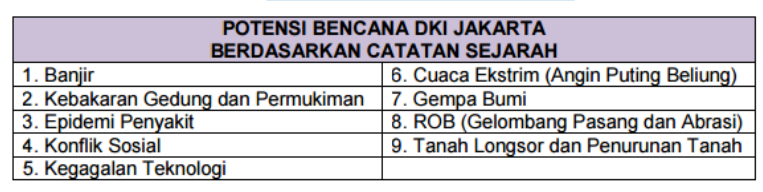

Jakarta sendiri terbagi menjadi beberapa wilayah, salah satunya Jakarta Pusat yang merupakan wilayan padat. Salah satunya Gunung Sahari, Lokasi gunung sahari yang berada diperkotaan yaitu Jakarta Pusat dan dipenuhi bangunan-bangunan padat, maka dibutuhkan pula jalur evakuasi bencana.

Salah satu elemen pembentuk kawasan perkotaan adalah jalur pedestrian, Shirvani (1985) mengatakan bahwa jalur pengguna pedestrian adalah bagian dari kota dimana orang bergerak dengan kaki, biasanya disepanjang sisi jalan, baik yang direncanakan atau terbentuk dengan sendirinya, yang menghubungkan satu tempat dengan tempat lainnya. Sehingga dapat disimpulkan bahwa 
jalur pedestrian merupakan jalur penghubung dari tempat satu ketempat lainnya, dan pada jalur inilah sangat berhubungan erat dengan jalur evakuasi bencana perkotaan. Sehingga penting untuk memperhatikan desain jalur pedestrian kaitannya dengan jalur evakuasi bencana di sebuah kawasan perkotaan.

Jalur pengguna pedestrian akan mampu berfungsi baik terhadap pengguna pedestrian dalam melakukan kegiatan menurut Sucher (1995 dalam Rohman, 2015) jika memenuhi peraturan sebagai berikut:

1. Continuity (kelancaran), pada umumnya pengguna pedestrian segala usia lebih menyukai untuk berjalan memutar dimana pengguna pedestrian dapat diketahui saat datang danpergi. Hal terpenting adalah rote menjadi lancar, dapat dilakukan sewaktuwaktu.

2. Length (jarak/lama/panjang). Jalur pengguna pedestrian tidak boleh terlalu panjang sehingga pengguna pedestrian dapat melalui beberapa pengguna pedestrian lain. Pengguna pedestrian harus dapat membuat kontrak mata dengan pengguna pedestrian lainnya agar terjadi kontaksosial.

3. Width (lebar/keluasan), beberapa pengguna pedestrian menyukai untuk jalan-jalan bersama, jadi sangatlah ideal jika jalur pengguna pedestrian memilikijalur yang cukup lebar untuk 2 orang berpapasan satu sama lainnya tanpa canggung untuk menyela suatu percakapan. Jalur pengguna pedestrian yang baik dan humanis bila terdapat elemen pendukung atau street furniture. Jalur pengguna pedestrian semakin penting jika pengguna pedestrian menjadi pengguna utama dari suatu area (Shirvani, 1985).

Dari kriteria diatas, maka sangatlah berkaitan dengan faktor-faktor pembentuk jalur evakuasi perkotaan, sehingga dapat dikatakan bahwa jalur pedestrian yang memiliki kriteria tersebut dapat dikatakan dapat dan layak menjadi jalur evakuasi.

Kondisi Pedestrian dikawasan Gunung Sahari:

Pedestrian di sebelah barat dikoridor ini sangat memenuhi kriteria sebagai pedestrian ways, yaitu dilengkapi dengan vegetasi, peneduh, aksesori pedestrian dsb. Namun jarang pengguna yang melaluinya, seperti dapat dilihat pada gambar di bawah ini
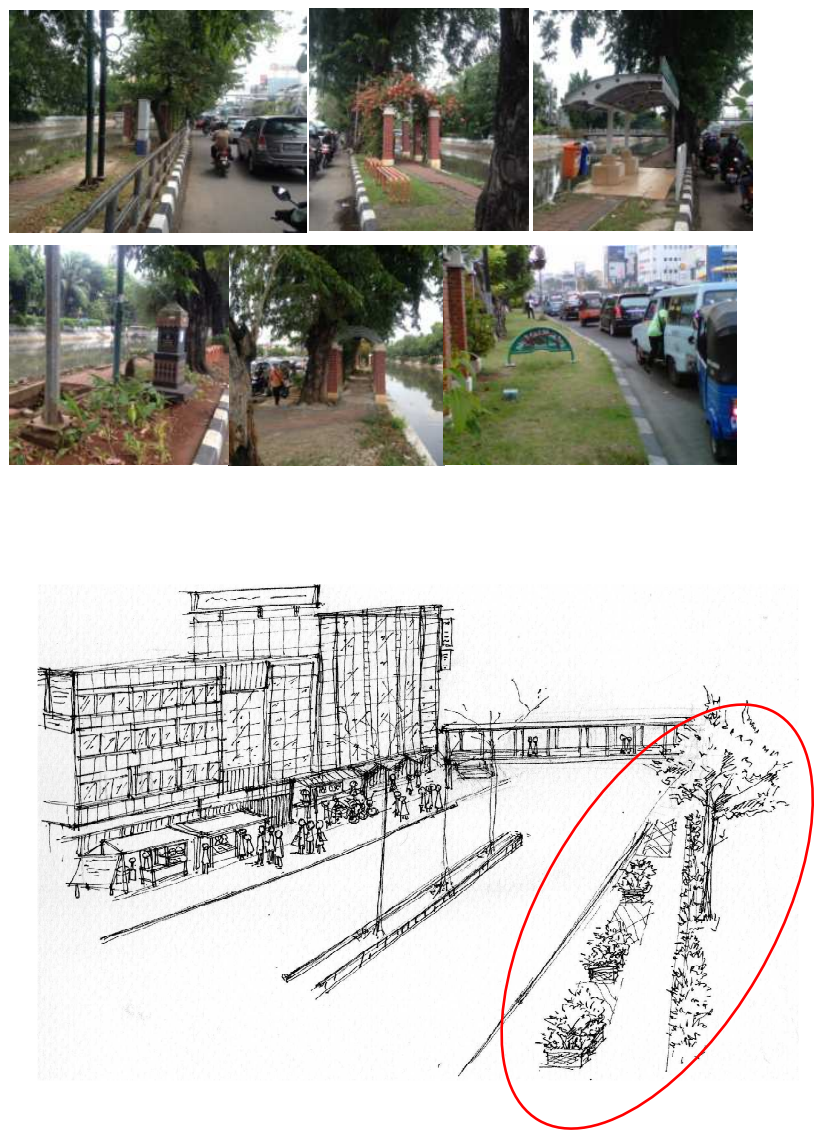

Gambaran tentang jumlah pejalan kaki tersebut dapat dilihat dalam uraian sebagai berikut :

a. Hampir setiap hari pejalan kaki mempunyai aktivitas di Jalan Gunung Sahari, mulai pagi sampai malam.

b. Kepadatan akan semakin berkurang pada saat hari libur atau hari Minggu. 
c. Kegiatan sebagian besar pejalan kaki di koridor Jalan Gunung Sahari adalah untuk kebutuhan pangan dan sandang

d. Sebagian besar aktivitas perjalanan di koridor Jalan Gunung Sahari pengguna kendaraan umum maupun pengguna kendaraan pribadi.

e. Pedagang Kaki Lima di sepanjang Jalan Gunung Sahari antara pagi hari, siang hari, sore hari dan malam hari bisa berbeda sehingga kegiatannya pun berbeda

f. Sebagian besar pengguna Jalan Gunung Sahari merupakan pegawai swasta/wiraswasta yang setiap harinya menggunakan jalur pedestrian

g. Bangunan Sepanjang koridor Jalan Gunung Sahari merupakan bangunan komersil.

kondisi lapangan di Gunung Sahari menurut Sucher (1995 dalam Rohman, 2015) adalah sebagai berikut :

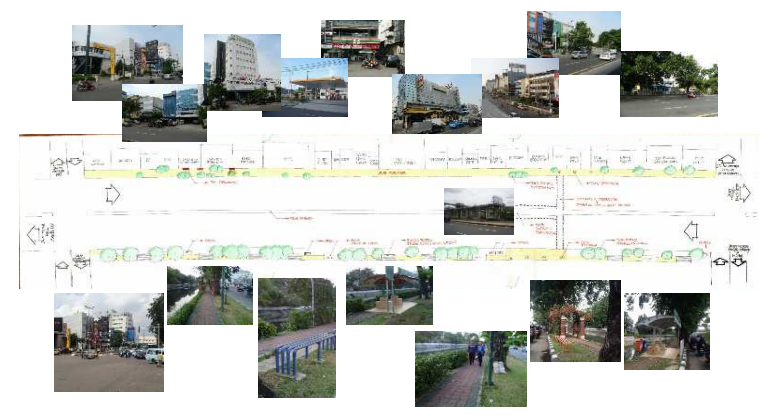

a. Continuity (kelancaran), padajalur pedestrian dikoridor jalan gunung sahari di sisi sebalah barat sangat lancar, namun disisi sebelah timur terjadi kepadatan dan sering tidak lancar untuk sirkulasi pejalan kakinya.

b. Length (jarak/lama/panjang). Jarak jalur pedestrian di koridor ini saa dengan panjang jalannya, dan bisa dikatakan cukup panjang untuk menghubungkan satu tempat ke tempat lainnya. c. Width (lebar/keluasan), Pada jalur pedestrian ini memiliki lebar 2 Meter sehingga bisa dikatakan cukup lebar, namun di sisi sebelah timur lebih sempit karena terdapat banyak aktifitas, seperti PKL, halte, ojeg, dll. Sedangkan disisi sebelah barat lebih luas, banyak terdapat vegetasi, street furniture, dan aksesoris jalur pedestrian.

Dapat disimpulkan bahwa jalur pedestrian sebelah timur lebih padat, sehingga menyebabkan ketidak lancaran, jalur menjadi sempit, dan orang yang melaluinya menjadi tidak lancar, hal ini disebabkan beberapa faktor, yaitu : aktifitas pendukung (Rohman, 2015). Dan disisi sebelah barat sangat potensial untuk dijadikan sebagai jalur evakuasi. Karena memenuhi kriteria sebagai berikut :
a. Lancar
b. Lebar dan
c. Jaraknya yang panjang.

Hal ini sesuai dengan kebijakan pemerintah yaitu, Pengembangan prasarana dan sarana pengurangan resiko bencana alamiah, dengan strategi :

1. Mengembangkan prasarana dan sarana untuk pengendalian banjir dengan pengembangan sistem polder, pemulihan dan pengembangan situ dan waduk, normalisasi sungai serta pembangunan tanggul pengaman sungai dan laut;

2. MengembangkankawasanPantai Utara sebagai upaya mengantisipasi perubahan iklim;

3. Memperbaiki dan meningkatkan sistem drainase kota;

4. Mengembangkan jalur, kawasan dan ruang evakuasi bencana;

5. Meningkatkan penyediaan ruang terbuka biru untuk antisipasi intensitas curah hujan;

6. Menciptakan kehidupan harmonis berdampingan dengan air; dan

7. Menyempurnakan peraturan bangunan dan lingkungannya yang 
lebih sesuai dengan ancaman bahaya di Jakarta misalnya gempa dan kebakaran.

Pemanfaatan jalur pedestrian menjadi jalur evakuasi bencana perkotaan menjadi salah satu pemecahan dari kebijakan nomor 4 dan 7. Dan Pada Jalur pedestrian di kawasan gunung Sahari ini bisa diterapkan, karena kriteria sudah sesuai dan desain sudah memenuhi persyaratan, hanya saja butuh campur tangan pemangku kebijakan untuk mensukseskan itu.

Sedangkan kebijakan lain adalah pengembangan prasarana dan sarana pengurangan resiko bencana non alam atau ulah manusia, dengan strategi :

1. Mengembangkan jalur, kawasan dan ruang evakuasi bencana;

2. Memberikan kemudahan akses bagi respon gawat darurat, terutama pada kawasankawasan perumahan padat; dan

3. Menyediakan prasarana dan sarana penanggulangan bencana.

Hal ini sangat mungkin terjadi di jalur pedestrian gunung sahari, jalur sebelah barat dapat dijadikan sebagai jalur evakuasi bencana perkotaan, sesuai dengan kebijakan nomor 1 , yaitu mengembangkan jalur, kawasan dan ruang evakuasi bencana.

\section{KESIMPULAN}

1. Jalur evakuasi bencana perkotaan harus dirancang sebagai satu kesatuan dengan pengembangan kawasan

2. Jalur pedestrian di kawasan gunung sahari disisi sebelah barat dapat dijadikan sebagai jalur evakuasi, karena memenuhi persyaratan jalur evakuasi perkotaan seperti :
- Lancar

- Lebar dan

- Jaraknya yang panjang.

3. \kebijakan pemerintan mengenai penanggulangan bencana dan jalur evakuasi dengan

Mengembangkanjalur, kawasandanruangevakuasibencanasan gatmungkinterjadi di jalur pedestrian gunungsahari, jalursebelahbaratdapatdijadikansebag aijalurevakuasibencanaperkotaan.

\section{DAFTAR PUSTAKa}

Carter, W. Nick. 1991. Disaster Management: A Disaster Manager's Handbook. Manila: ADB

Mauliani, dkk, 2013, "KajianJalur Pedestrian SebagaiRuang Terbuka Pada Area Kampus" JurnalArsitektur NALARs Volume 12 No 2 Juli 2013

Pedoman Rencana Penanggulangan bencara Jakarta 2013-2017

Rohman, Abdur. 2015, "KajianPemilihanJalur Pedestrian Ways Ditinjau Dari PresepsiPengguna Di KoridorJalanGunungSahari Jakarta" Tesis Magister TeknikArsitekturUniversitasDiponegoro

Rubenstein, Harvey M. 1992. Pedestrian Malls, Streetcapes, and Urban Spaces. John Wiiley and Sons: USA

Shirvani, Hamid. 1985. The Urban Design Process. Van Nostrand Reinhold Company. New York.

UU No 24 tahun 2007 tentangpenanggulanganbencana 
